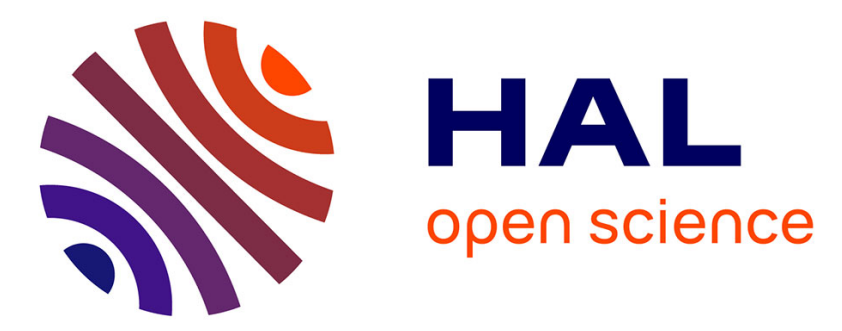

\title{
Review of fruit genetics and breeding programmes and a new European initiative to increase fruit breeding efficiency
}

Francois Laurens, M.J. Aranzana, D. Bassi, J. Bonany, L. Corelli, Charles Eric Durel, J. Mes, Thierry Pascal, A. Peil, Bénédicte Quilot-Turion, et al.

\section{To cite this version:}

Francois Laurens, M.J. Aranzana, D. Bassi, J. Bonany, L. Corelli, et al.. Review of fruit genetics and breeding programmes and a new European initiative to increase fruit breeding efficiency. Acta Horticulturae, 2012, 929, pp.95-102. hal-01209943

\section{HAL Id: hal-01209943 \\ https://hal.science/hal-01209943}

Submitted on 29 May 2020

HAL is a multi-disciplinary open access archive for the deposit and dissemination of scientific research documents, whether they are published or not. The documents may come from teaching and research institutions in France or abroad, or from public or private research centers.
L'archive ouverte pluridisciplinaire HAL, est destinée au dépôt et à la diffusion de documents scientifiques de niveau recherche, publiés ou non, émanant des établissements d'enseignement et de recherche français ou étrangers, des laboratoires publics ou privés. 


\title{
Review of Fruit Genetics and Breeding Programmes and a New European Initiative to Increase Fruit Breeding Efficiency
}

\author{
F. Laurens ${ }^{1}$, M.J. Aranzana ${ }^{2}$, P. Arús ${ }^{2}$, D. Bassi ${ }^{3}$, J. Bonany $^{4}$, L. Corelli $^{5}$, C.E. Durel ${ }^{1}$, \\ J. Mes 6 , T. Pascal ${ }^{7}$, A. Patocchi ${ }^{8}$, A. Peil ${ }^{9}$, B. Quilot ${ }^{7}$, S. Salvi ${ }_{6}$, S. Tartarini ${ }^{5}$, \\ M. Troggio ${ }^{10}$, A. Vecchietti $^{11}$, R. Velasco $^{10}$ and E. van de Weg ${ }^{6}$ \\ INRA, Angers-Nantes, Genetics and Horticulture (GenHort) JRU, Beaucouzé, France \\ IRTA Cabrils (Barcelona), Spain \\ Università degli Studi di Milano, Dipartimento di Produzione Vegetale, Milano, Italy \\ 4 IRTA Mas Badia, La Tallada, Spain \\ 5 University of Bologna, Dipartimento Colture Arbore, Bologna, Italy \\ 6 DLO, Plant Research International, Wageningen, The Netherlands \\ 7 INRA Avignon, Fruit and Vegetable Genetics and Breeding Unit, Avignon, France \\ 8 ACW Research Station, Wädenswil, Switzerland \\ 9 JKI, Institute for Breeding Research on Horticultural and Fruit Crops, Dresden, \\ Germany \\ ${ }_{11}$ FEM, IASMA Research Centre, San Michele all'Adige (TN), Italy \\ 11 Parco Tecnologico Padano, Lodi, Italy
}

Keywords: apple and peach breeding, genetics, genomics

\begin{abstract}
The European fruit industry is facing economic challenges imposed by increasingly fierce international competition and decreasing fruit consumption, societal demand for a more sustainable production, and biological problems caused by climate changes. Releasing new cultivars that meet these challenges is a major goal of all European breeding programmes. However, addressing them has been slow due to the nature of fruit tree breeding: long term, low efficiency and high cost. For the past 15 years, efficient networks of fruit geneticists and genomicists have progressively been built thanks in particular to EU-funded projects. Europe has thus become a leader in research on fruit genetics aimed at enhancing fruit quality traits as well as resistance to biotic stresses. European teams working on fruit genetics have developed up-to-date tools and skills covering most of the "omics" fields as well as statistics and software development. Although fruit breeding is very active in Europe, very few breeding programmes are really using the output of the fruit genetics/genomics research. A few bottlenecks can explain this situation. To solve that, a new European initiative has been set up by the FruitBreedomic. This large collaborative project, has the strategic goal of improving the efficiency of current fruit breeding programmes by bridging the existing gap between molecular genetics research and application in breeding.
\end{abstract}

\section{INTRODUCTION}

Major fruit tree crops such as apple (Malus $\times$ domestica Bork), peach and nectarine (Prunus persica (L.) Batsch), pear (Pyrus communis L.), plum (Prunus domestica L.), sweet (Prunus avium L.) and sour cherries (Prunus cerasus L.), apricot (Prunus armeniaca L.) and nuts such as almonds (Prunus dulcis Miller, D.A. Webb) all belong to the Rosaceae family. With $4.8 \mathrm{M}$ ha and a production close to $70 \mathrm{M} \mathrm{mt}$, apple is the fourth fruit crop grown worldwide just behind the Citrus group, bananas and grapes (www.faostat.fao.org, 2008), The world production of peaches and nectarines is also significant (18 M mt in 2008). After grape (25 M mt), apple is the second greatest fruit produced in Europe (12 M mt in 2008). Within the Rosaceae family, peaches and nectarines $( \pm 4 \mathrm{M} \mathrm{mt})$ come in next, followed by pears $(2.5 \mathrm{M} \mathrm{mt})$; plums and sloes $(1.3 \mathrm{M}$ $\mathrm{mt})$, sweet and sour cherries $(0.8 \mathrm{M} \mathrm{mt})$ and apricots $(0.6 \mathrm{M} \mathrm{mt})$.

The rosaceous crop industries face numerous limitations to profitability and sustainability. Apart from worldwide macro-economic reasons, many other factors are 
contributing to the decreasing cropping trend foreseen for the coming years; on the farms, expenses increased dramatically mainly because of labour costs which represent on average more than half of the farm costs for apple and peach (ONIFLHOR, 2005). Fruit consumption is slowly decreasing in Europe; this has been attributed in peach to low quality of fruit harvested at an immature stage (Sansavini et al., 2006). Furthermore, most of the commercial cultivars are host to a wide range of pests and diseases that need to be controlled for commercial production to be profitable. In apple and peach orchards, 15 to 20 chemical sprays on average are necessary to control the two most damaging diseases.

Breeding for new high quality fruit cultivars with genetic resistance to various pests and diseases is necessary to improve fruit consumption in Europe and to reduce the negative impacts of pesticides on human health and the environment. In addition, breeding also needs to take into account the new threats posed by climatic changes, the first effects of which have already been expressed in fruit tree production (Legave et al., 2008).

\section{STATE OF THE ART OF APPLE AND PEACH BREEDING AND GENETICS}

\section{Breeding Situation}

Fruit breeding is particularly active in Europe where during the last five years, $>50$ CPVO peach applications have been delivered each year for new cultivars of which more than one half are from European origin (CPVO meeting, Paris, 2007). In 2005 at least 32 dessert apple scion breeding programmes were active (Lespinasse, 2005, pers. commun.; Laurens, 2005). However, the breeding practices that have yielded today's best cultivars have remained almost unchanged for the last 50 years. Decisions regarding parent choice for crossing and progeny selection for advancing elite plants are often based on empirical knowledge (phenotypic and mass selection). Furthermore, breeding of woody fruit crops is hampered by morphological, physiological and cultural constraints specific to each crop (Lauri and Laurens, 2005).

The genetic basis of most breeding programmes is very narrow (Laurens, 1999; Noiton and Alspach, 1996; Scorza et al., 1985) as the world apple production predominantly relies on either chance seedlings ('Golden Delicious', 'Red Delicious', 'Braeburn', 'McIntosh', 'Jonathan') or selections derived from these cultivars through controlled hybridization: 'Elstar', 'Gala', 'Jonagold' and more recently 'Pink Lady ${ }^{,}$, all derived from 'Golden Delicious' or 'Fuji', a progeny of 'Red Delicious'. New apple cultivars resistant to scab are being developed. They are derived from several generations of crossing often started from crab-apple progenitors, but predominantly stemmed from one resistance donor, $M$. floribunda clone 821 . This uniformity is a big threat since it has been proven that the $R v i 6 / V_{f}$ resistance gene is overcome by new virulent strains of $V$. inaequalis rendering this resistance gene ineffective (Parisi et al., 1993, 2004; Roberts and Crute, 1994). New strategies based on the use of a wide diversity of qualitative and quantitative sources of resistance are in progress (Foulongne et al., 2003; Laurens et al., 2004; Patocchi et al., 2009) but it will take a long time to release new cultivars developed from this germplasm.

Due to its self compatibility, peach behaves as a partly self-pollinating species (Miller et al., 1989) and its level of variability is much lower than self-incompatible fruit trees including other stone fruits and apple (Byrne, 1990; Aranzana et al., 2010). Moreover, most cultivars of Europe and North America come from a few founders that were used in the early USA breeding programmes contributing to its very low genetic basis (Scorza et al., 1985). Many small breeding programmes, mostly private, supply a large number of cultivars for a high demand from the growers. However, the new cultivars have not been able to solve some of the major challenges for the sustainability of production (no cultivars resistant to the main diseases), commercialization (short shelf life) and consumer needs (constant and predictable fruit taste and texture).

In many crops, even though genetic and genomic studies have been developed at a very high level, the application of Molecular Assisted Breeding (MAB) is still limited to 
very few and simply inherited traits (Dekkers and Hospital, 2002). MAB implementation in Rosaceae breeding programmes has been minimal and has been used mainly for disease resistance and fruit quality traits with Mendelian inheritance (Bassil and Lewers, 2009; Peace et al., 2009).

\section{Genetic/Genomic Studies}

For the past 20 years, thanks to the development of molecular technologies and international collaborations, significant progress has been made in our understanding of the genetics of the main horticultural traits. Apple and peach are the rosaceous crops in which marker identification and mapping are most advanced. In fact, in these two crops several key traits related to pathogen/pest resistance and fruit quality have been mapped in the last years, leading to a better understanding of their genetic architecture/ determinism. These results have been reviewed by Abbott et al. (2007), Arús and Gardiner (2007), Gardiner et al. (2007) and Bus et al. (2009).

EST profiling studies have also been widely conducted in Rosaceae with over $250,000 \mathrm{EST}$ sequences available in public databases for $M$. $\times$ domestica and over 80,000 for P. persica (Arús and Gardiner, 2007). These data have been useful to monitor the expression of various genes. Functional genetics has also recently contributed to the discovery of numerous candidate genes for various traits: disease resistance (Baldi et al., 2004; Lalli et al., 2005; Calenge et al., 2005; Broggini et al., 2009), ethylene pathway (Costa et al., 2005), fruit texture (Peace et al., 2005; Costa et al., 2005, 2008), sugar and acid content (Etienne et al., 2002), as well as fruit flesh colour (Chagné et al., 2007). In contrast, few genes of interest were cloned such as Rvi6/Vf and Rvi15/Vr2 scab resistance genes for apple (Belfanti et al., 2004; Galli et al., 2010) or in advanced stage of mapbased cloning such as nematode resistance (Claverie et al., 2004) and the $D$ gene controlling the non-acidity in peach (Boudehri et al., 2009). New cloning projects are in progress. Today the important crops of the Rosaceae are beginning to enjoy the same benefits once confined to model plants, the pinnacle of which is the generation of whole genome sequences (WGS) for both apple and peach.

\section{Genome Sequencing and Genomic Tools}

The Peach Genome Sequencing Initiative is an international collaborative project involving mainly Italian and USA research institutions (Sosinski et al., 2009). A double haploid of 'Lovell' was chosen to obtain the draft sequence of the genome with WGS strategy using the Sanger methodology.

An international consortium led by FEM (Fondazione Edmund Mach) recently completed the genome sequencing of the diploid 'Golden Delicious' (Velasco et al., 2010). The sequencing was carried out based on the shot-gun approach using the sequencing-by-synthesis approach of 454-Roche technology (Shendure and Ji, 2008). About $80 \%$ of the genome, including $>90 \%$ of the genes, was assembled in scaffolds and c. $70 \%$ anchored to the apple linkage map using 1,700 molecular markers. As expected, the 'Golden Delicious' genome is highly heterozygous, with the number of discovered single nucleotide polymorphisms (SNPs) approaching 2 million.

\section{FruitBreedomics, a New European Initiative to Improve the Efficiency of Apple Breeding with New Technologies}

An international consortium has designed FruitBreedomics, an ambitious research project which aims to improve and make use of the latest methodologies, technologies and knowledge to improve the efficiency of current fruit breeding programmes. Its strategic aim is to bridge the existing gap between molecular genetic research and breeding. It will focus primarily on apple and peach, two major fruits in Europe, but many tools and much knowledge gained will also be of benefit to other species of the Rosaceae family via the strong genomic and functional ancestral relatedness among these species.

A major breeding tool to be developed is a validated pipeline for Marker Assisted Breeding and its implementation in ongoing commercial breeding programs. 
FruitBreedomics will prepare for and make available to the consortium selected prebreeding material. It will also evaluate a way to reduce the introgression time of new traits from wild species to pre-breeding material with advanced fruit quality by inducing early flowering thanks to fast-breeding technology (Flachowsky et al., 2009).

The research efforts will be directed to improve our understanding of the genetics of some major horticultural traits and develop innovative research tools to efficiently find marker trait associations in breeding and genebank germplasm. To overcome the main issues of the past genetic studies on fruit trees (narrow genetic diversity, low mapping density, single environment), FruitBreedomics will focus on two innovative and complementary genetic mapping approaches based on a wider genetic diversity: i) pedigree-based analysis (PBA) and ii) linkage disequilibrium (LD) mapping over the whole genome, i.e., genome-wide association (GWA) mapping.

Additionally, the project aims at increasing the accessibility of breeders to the genetic diversity present in germplasm collections, thus contributing to widening the genetic basis of cultivated fruit trees. To implement the scientific approach, FruitBreedomics will be built on two research pillars ("the European Breeding Platform" and the Diversity and QTL mapping pillar), one research work package (new traits knowledge), one support pillar (tool and data management) (Fig. 1).

FruitBreedomics has been accepted by the European Commission in the frame of the seventh Framework Programme. It will start in March 2011 and end in 2015. It regroups 24 participants including four non EU countries.

\section{CONCLUSION}

The European fruit industry is facing economic challenges imposed by increasingly fierce international competition and decreasing fruit consumption, the high demand for a more sustainable production and the biological problems caused by climate change. Releasing new cultivars that meet these challenges is a major goal of all European breeding programmes, but response to address them has been slow due to the nature of fruit tree breeding: long-term, low-efficiency and hence high costs.

FruitBreedomics has as the strategic goal of improving the efficiency of current fruit breeding programmes by bridging the existing gap between molecular genetics research and application in breeding. It will tackle this task following a multidisciplinary approach, including genetics, genomics, transcriptomics, ecophysiology and bioinformatics. FruitBreedomics will provide the fruit tree sector with cutting-edge breeding tools to improve selection efficiency as well as superior pre-breeding material to meet grower and consumer demands for cultivars that can be grown in sustainable agricultural systems in the context of climate change. The project will develop tailored molecular and bioinformatics tools to extensively exploit the diversity present in European germplasm collections and breeding populations. This will lead to the selection of desired favourable genes needed for improvement of main horticultural traits. The collected data will provide precious genetic information on the pool of genitors and founders to be used in future breeding programmes.

The consortium aims at setting up a collaborative European network of breeders, genebank curators and industry representatives with the aim of rapidly and widely disseminating and implementing the obtained results among all interest European stakeholders. FruitBreedomics will liaison international partners with complementary expertises to help building or consolidating networks and make the best use of genetics/ genomic tools for research and breeding.

\section{ACKNOWLEDGEMENTS}

The authors would like to thank all the participants of the FruitBreedomics consortium who contributed to the preparation and the redaction of the proposal. This publication does not necessarily reflect the European Commission's views. 


\section{Literature Cited}

Abbott, A.G., Arús, P. and Scorza, R. 2007. Peach. p.137-156. In: C. Kole (ed.), Genome Mapping and Molecular Breeding in Plants. Fruits and Nuts, Vol. 4. Springer, Berlin.

Aranzana, M.J., Abbassi, E.K., Howad, W. and Arús, P. 2010.Genetic variation, population structure and linkage disequilibrium in peach commercial varieties. BMC Genetics (accepted).

Arús, P. and Gardiner, S. 2007. Genomics for improvement of Rosaceae temperate tree fruit. p.357-397. In: R.K. Varshney and R. Tuberosa (eds.), Genomics-Assisted Crop Improvement, Volume 2 Genomics applications in Crops. Springer (Dordrecht).

Baldi, P., Patocchi, A., Zini, E., Toller, C., Velasco, R. and Komjanc, M. 2004. Cloning and linkage mapping of resistance gene homologues in apple. Theor. Appl. Genet. 109:231-239.

Bassil, N. and Lewers, K. 2009. Genomics opportunities, new crops and new products. p.55-70. In: K.M. Folta and S.E. Gardiner (eds.), Genetics and Genomics of Rosaceae, Plant Genetics and Genomics: Crops Models 6.

Belfanti, E., Silfverberg-Dilworth, E., Tartarini, S., Patocchi, A., Barbieri, M., Zhu, J., Vinatzer, B.A., Gianfranceschi, L., Gessler, C. and Sansavini,S. 2004. The HcrVf2 gene from a wild apple confers scab resistance to a trasngenic cultivated variety. Proc. Natl. Acad. Sci. USA 101:886-890.

Boudehri, K., Bendahmane, A., Cardinet, G., Troadec, C., Moing, A. and Dirlewanger, E. 2009. Phenotypic and fine genetic characterization of the D locus controlling fruit acidity in peach. BMC Plant Biol. 9:59.

Broggini, G.A.L., Galli, P., Parravicini, G., Gianfranceschi, L., Gessler, C. and Patocchi, A. 2009. HcrVf paralogs are present on linkage groups 1 and 6 of Malus. Genome 52:129-138.

Bus, V.G.M., Esmenjaaud D., Buck, E. and Laurens, F. 2009. Application of genetic markers in rosaceous crop. p.563-599. In: K.M. Folta and S.E. Gardiner (eds.), Genetics and Genomics of Rosaceae, Plant Genetics and Genomics: Crops Models 6.

Byrne, D.H. 1990. Isozyme variability in four diploid stone fruits compared with other woody perennial plants. J. Hered. 81:68-71.

Calenge, F., van der Linden, C.G., van de Weg, W.E., Schouten, H.J., van Arkel, G., Denancé, C. and Durel, C.-E. 2005. Resistance genes analogues identified through the NBS-profiling method map close to major genes and QTL for disease resistance in apple. Theor. Appl. Genet. 110:660-668.

Chagné, D., Carlisle, C.M., Blond, C., Volz, R.K., Whitworth, C.J., Oraguzie, N.C., CrowHust, R.N., Allan, A.C., Espley, R.V., Hellens, R.P. and Gardiner, S.E. 2007. Mapping a candidate gene (MdMYB10) for red flesh and foliage colour in apple. BMC Genomics 2:212.

Claverie, M., Dirlewanger, E., Cosson, P., Bosselut, N., Lecouls, A.C., Voisin, R., Kleinhentz, M., Lafargue, B., Caboche, M., Chalhoub, B. and Esmenjaud, D. 2004. High-resolution mapping and chromosome landing at the root-knot nematode resistance locus Ma from Myrobalan plum using a large-insert BAC DNA library. Theor. Appl. Genet. 109:1318-1327.

Costa, F., Stella, S., Van de Weg, W.E., Guerra, W., Cecchinel, M., Dallavia, J., Koller, B. and Sansavini, S. 2005. Role of the genes Md-ACO1 and Md-ACS1 in ethylene production and shelf life of apple (Malus domestica Borkh). Euphytica 141:181-190.

Costa, F., Van de Weg, W.E., Stella, S., Dondini, L., Pratesi, D., Musacchi, S. and Sansavini, S. 2008. Map position and functional allelic diversity of Md-Exp7, a new putative expansin gene associated with fruit softening in apple (Malus $\times$ domestica Borkh.) and pear (Pyrus communis ). TGG 4:575-586.

Dekkers, J.C. and Hospital, F. 2002. The use of molecular genetics in the improvement of agricultural populations. Nat. Rev. Genet. 3:22-32.

Etienne, C., Moing, A., Dirlewanger, E., Raymond, P., Monet, R. and Rothan, C. 2002. Isolation and characterization of six peach cDNAs encoding key proteins in organic acid metabolism and solute accumulation: involvement in regulating peach fruit 
acidity. Physiol. Plant. 114:259-270.

Flachowsky, H., Hanke, M.V., Peil, A., Strauss, S.H. and Fladung, M. 2009. A review on transgenic approaches to accelerate breeding of woody plants. Plant Breed. 128:217226.

Foulongne, M., Pascal, T., Arús, P. and Kervella, J. 2003. The potential of Prunus davidiana for introgression into peach [Prunus persica (L.) Batsch] assessed by comparative mapping. Theor. Appl. Genet. 107:227-238.

Galli, P., Patocchi, A., Broggini, G.A.L. and Gessler, C. 2010. The Rvi15 (Vr2) apple scab resistance locus contains three TIR-NBS-LRR genes. MPMI 23:608-617.

Gardiner, S.E., Bus, V.G.M., Rusholme, R.L., Chagné, D. and Rikkerink, E.H.A. 2007. Apple. p.1-62. In: C. Kole (ed.), Genome Mapping and Molecular Breeding in Plants. Fruits and Nuts, Vol. 4. Springer, Berlin.

Lalli, D.A., Decroocq, V., Blenda, A.V., Schurdi-Levraud, V., Garray, L., Le Gall, O., Damsteegt, V., Reighard, G.L. and Abbott, A.G. 2005. Identification and mapping of resistance gene analogs (RGAs) in Prunus: a resistance map for Prunus. Theor. Appl. Genet. 111:1504-1513.

Laurens, F. 1999. Review of the current apple breeding programmes in the world: objectives for scion cultivar improvement. Acta Hort. 484:163-170.

Laurens, F. 2005. Research developed on the genetics of apple and their application in the current breeding programmes. p.15-19. In: F.B. Fialho, H.P. dos Santos and P.R.D. de Oliveira (eds.), Proc. Embrapa Symposium on Temperate Fruit Researches. Bento Gonçalves RS.

Laurens, F., Chevalier, M., Dolega, E., Gennari, F., Goerre, M., Fischer, C., Kellerhals, M., Lateur, M., Lefrancq, B., Parisi, L., Shouten, H.J. and Tartarini, S. 2004. Local European cultivars as sources of durable scab resistance in apple. Acta Hort. 663:115122.

Lauri, P.E. and Laurens, F. 2005. Architectural types in apple (Malus $\times$ domestica Borkh.) - concepts and use for tree management and genetic improvement in France. p.13001313. In: R. Dris (ed.), Crops: growth, quality and biotechnology, Haworth Press, Helsinki (Finland).

Legave, J.M., Farrera, I., Alméras, T. and Calleja, M. 2008. Selecting models of apple flowering time and understanding how global warming has had an impact on this trait. J. Hort. Sci. Biotech. 83:76-84.

Miller, P.J., Parfitt, D.E. and Weinbaum, S.A. 1989. Outcrossing in peach. HortScience 24:359-360.

Noiton, D. and Alspach, P.A. 1996. Founding clones, inbreeding, coancestry and status number of modern apple cultivars. J. Amer. Soc. Hort. Sci. 121:773-782.

Onifhlor. 2005. Observatoire des exploitations fruitières: résultats 2004. Oniflhor, Ctifl, FNPF. CNCER, Paris.

Parisi, L., Lespinasse, Y., Guillaumes, J. and Kruger, J. 1993. A new race of Venturia inaequalis virulent to apples with resistance due to the Vf gene. Phytopathology 83:533-537.

Parisi, L., Fouillet, V., Schouten, H.J., Groenwold, R., Laurens, F., Didelot, F., Evans, K., Fischer, C., Gennari, F., Kemp, H., Lateur, M., Patocchi, A., Thissen, J. and Tsipoudiris, C. 2004. Variability of pathogenicity of Venturia inaequalis in Europe. Acta Hort. 663:107-113.

Patocchi, A., Frey, A., Frey, J.E. and Kellerhals, M. 2009. Towards improvement of marker assisted selection of apple scab resistant cultivars: Venturia inaequalis virulence surveys and standardization of molecular marker alleles associated with resistance genes. Mol. Breed. 24:337-347.

Peace, C.P., Crisosto, C.H. and Gradziel, T.M. 2005. Endopolygalacturonase: a candidate gene for freestone and melting flesh in peach. Mol. Breed. 16:21-31.

Peace, C.P., Olmstead, J.W., Iezzoni, A.F. and Bliss, F.A. 2009. Current opportunities for marker-assisted selection in Rosaceae crops. Plant and Animal Genome XVII San Diego January 10-14 2009, Oral Abstract W215. 
Roberts, A.L. and Crutes, I.R. 1994. Apple scab resistance from Malus floribunda 821 (Vf) is rendered ineffective by isolates of Venturia inaequalis from Malus floribunda. Norw. J. Agric. Sci. 17:403-406.

Sansavini, S., Gamberini, A. and Bassi, D. 2006. Peach breeding, genetics and new cultivar trends. Acta Hort. 713:23-48.

Scorza, R., Mehlenbacher, S.A. and Lightner, G.W. 1985. Inbreeding and coancestry of freestone peach cultivars of the Eastern United States and implications for peach germplasm improvement. J. Amer. Soc. Hort. Sci. 110:547-552.

Shendure, J. and Ji, H. 2008. Next-generation DNA sequencing. Nat. Biotechnol. 26:1135-1145.

Sosinski, B., Shulaev, V., Dhingra, A., Kalyanaraman, A., Bumgarner, R., Rokhsar, D., Verde, I., Velasco, R. and Abbott, A.G. 2009. Rosaceaous Genome Sequencing: Perspectives and Progress. p.601-615. In: K.M. Folta and S.E. Gardiner (eds.), Genetics and Genomics of Rosaceae, Plant Genetics and Genomics: Crops and Models 6.

Velasco, R., Zharkikh, A., Affourtit, J., Dhingra, A., Cestaro, A., Kalyanaraman, A., Fontana, P., Bhatnagar, S., Troggio, M., Pruss, D., Salvi, S., Pindo, M., Baldi, P., Cavaiuolo, M., Coppola, G., Costa, F., Cova, V., Dal Ri, A., Goremykin, V., Komjanc, M., Longhi, S., Magnago, P., Malacarne, G., Malnoy, M., Micheletti, D., Moretto, M., Perazzolli, M., Si Ammour, A., Vezzulli, S., Zini, E., Eldredge, G., Fitzgerald, L.M., Gutin, N., Lanchbury, J., Macalm, T., Mitchell, J.T., Reid, J., Wardell, B., Chen, Z., Desany, B., Niazi, F., Palmer, M., Koepke, T., Jiwan, D., Schaeffer, S., Krishnan, V., Wu, C., Chu, V.T., King, S.T., Vick, J., Tao, Q., Mraz, A., Stormo, A., Stormo, K., Bogden, R., Ederle, D., Stella, A., Vecchietti, A., Kater, M.M., Masiero, S., Lasserre, P., Lespinasse, Y., Allan, A.C., Bus, V., Chagné, D., Crowhurst, R.N., Gleave, A.P., Lavezzo, E., Fawcett, J.A., Proost, S., Rouzé, P., Sterck, L., Toppo, S., Lazzari, B., Hellens, R.P., Durel, C.-E., Gutin, A., Bumgarner, R.E., Gardiner, S.E., Skolnick, M., Egholm, M.., Van de Peer, Y., Salamini, F. and Viola, R. 2010. The apple genome: emergence of the species and its domestication. Nat. Gen. 42:833-839. 


\section{Figures}

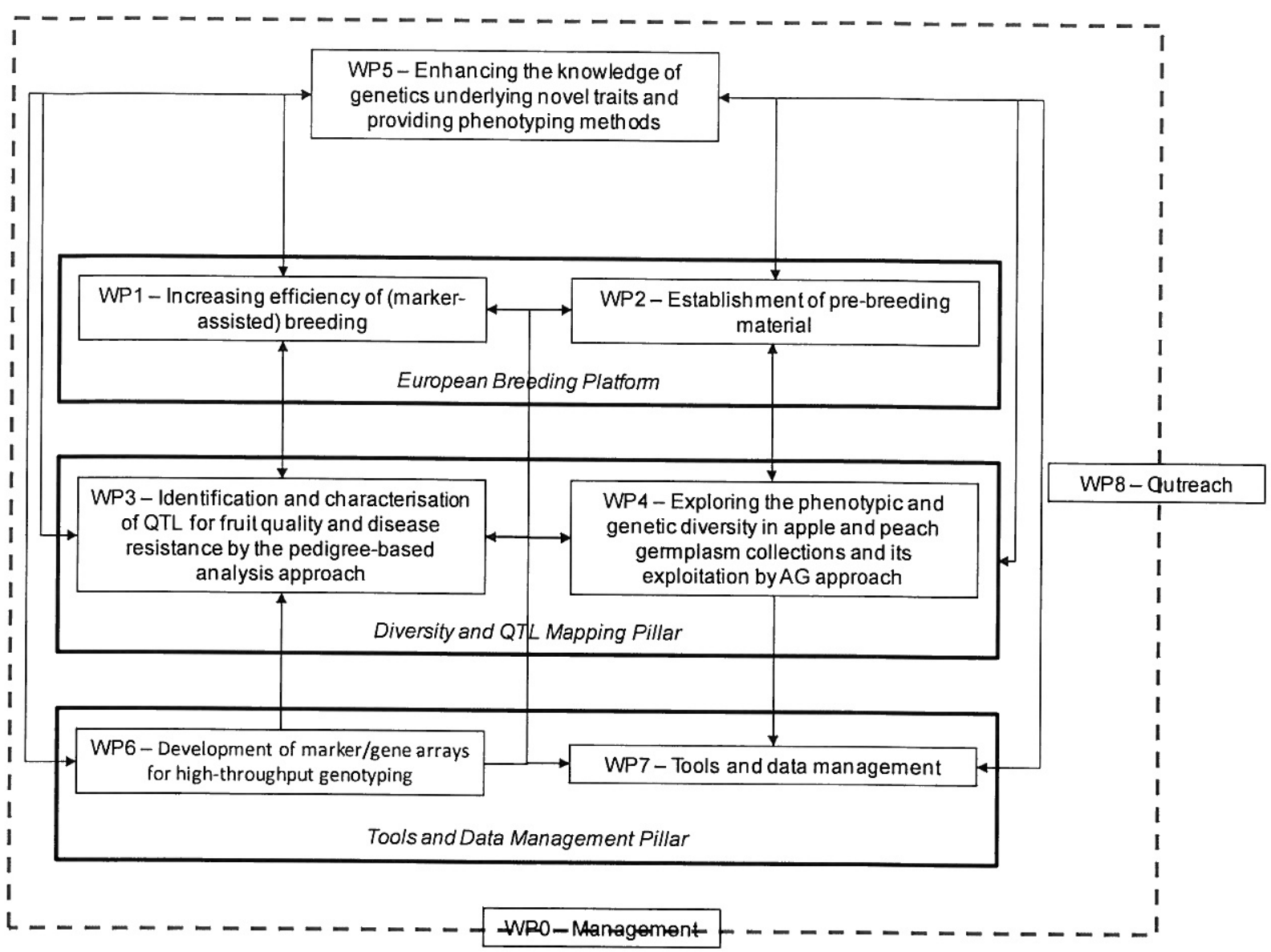

Fig. 1. Structure of the EU-FruitBreedomics project. 